\title{
The Influence of Outward Foreign Direct Investment on Enterprise Technological Innovation
}

\author{
Chenggang Wang, ${ }^{1}$ Tiansen Liu $\mathbb{D}^{2,3,4}$ and Jinliang Wang ${ }^{1}$ \\ ${ }^{1}$ College of Economics and Business Administration, Heilongjiang University, Harbin, China \\ ${ }^{2}$ School of Economics and Management, Harbin Engineering University, Harbin, China \\ ${ }^{3}$ School of Social and Behavioral Sciences, Nanjing University, Nanjing, China \\ ${ }^{4}$ State Key Laboratory of Pollution Control and Resource Reuse, Nanjing University, Nanjing, China \\ Correspondence should be addressed to Tiansen Liu; tiansen0328@hotmail.com
}

Received 1 December 2020; Revised 25 January 2021; Accepted 26 February 2021; Published 9 March 2021

Academic Editor: Harish Garg

Copyright () 2021 Chenggang Wang et al. This is an open access article distributed under the Creative Commons Attribution License, which permits unrestricted use, distribution, and reproduction in any medium, provided the original work is properly cited.

\begin{abstract}
As the scale of China's outward foreign direct investment (OFDI) continues to expand, more and more scholars have begun to discuss the influence of OFDI on enterprise technological innovation. In order to be able to deeply explore the impact of enterprises' OFDI activities on enterprise technological innovation, this paper combines relevant enterprise data from 2015 to 2017 and uses the new method to test the "technological innovation effect" produced by the OFDI of Chinese enterprises. Finally, this paper concluded that the development of OFDI activities of enterprises can promote the improvement of the level of technological innovation of enterprises, and this promotion has a lag effect. R\&D-type OFDI activities play a vital role in promoting the ability of technological innovation of enterprises. Compared with low-income host countries, investment in highincome host countries has a greater effect on promoting the ability of technological innovation of enterprises.
\end{abstract}

\section{Introduction}

In the context of increasing industrialization, the scale of OFDI by China's enterprises is expanding. According to data from the "2018 China's OFDI Statistical Bulletin" released by the Ministry of Chinese Commerce, Chinese National Bureau of Statistics, and Chinese State Administration of Foreign Exchange, China's OFDI flow was US $\$ 143.04$ billion in 2018, making it the world's second largest OFDI outflow country. China's OFDI stock reaches 1.98 trillion US dollars, ranking it third in the OFDI stock rankings of all countries and regions in the world, only behind the United States and the Netherlands. In addition, China's economic influence in global OFDI continues to expand. In 2018, China's OFDI flow accounted for $14.1 \%$ of global flow. At the end of 2018, China's OFDI stock accounted for $6.4 \%$ of the global OFDI stock, both hitting record highs. With the increasing scale of OFDI, the issue of OFDI in China has become a hot issue in academic research.
The main research question of this paper is as follows: What is the impact of OFDI on enterprise technological innovation? That is, to explore whether there is a "technical innovation effect" in the process of enterprises carrying out OFDI or not? The "technical innovation effect" in OFDI mainly refers to the increase of intellectual capital investment and technology absorption in OFDI, which promotes the improvement of the level of technological innovation of enterprises. Based on the relevant research literature of scholars, it can be seen that some scholars have carried out certain research on OFDI, technological innovation, and the impact of OFDI on technological innovation.

Some scholars have studied the related issues on OFDI from different perspectives. Buckley [1] mainly studied the relevant factors affecting OFDI activities of China's enterprises, such as investment strategy, enterprise-related production factor endowments, and investment industry status. Alon [2] researched the large-scale development of China's state-owned enterprises, but the injection of OFDI from 
foreign enterprises is still needed, because attracting foreign capital can stimulate the sustainable development of related industries more efficiently in China. Verbeke [3] mainly explored the key factors of China's OFDI based on the relevant data from 2008 to 2017, and pointed out that the investment environment of the host country is the most critical factor. When Nie [4] studied the specific role of OFDI in China, he focused on the economic effects between OFDI and economic development, and believed that OFDI in China can indirectly stimulate the development and progress of the domestic economy. When Zhang Qian [5] researched the OFDI of countries along the "Belt and Road," he believed that in the process of choosing the location of foreign direct investment, Chinese enterprises are mainly affected by the relationship between the host country and the home country. Borghesi [6] conducted a study based on the data of 22,000 Italian manufacturing enterprises that carried out ODFI in Europe, and believed that the EU's emissions trading system had little impact on the number of subsidiaries established in Italy, but it had a greater impact on the production efficiency of subsidiaries. Especially in trade-intensive industries, this situation is more common.

There are also some scholars who have studied related issues on the firm technological innovation. When Cantwell [7] studied the relationship between the technological innovation and the development of multinational enterprises, he pointed out that the level of technological innovation was a decisive factor affecting the international economic activities and production efficiency of enterprises. Abernathy [8] proposed the definition of the connotation of technological innovation in research, and believed that technological innovation mainly included process innovation and product innovation, and used the A-U model to point out the connection between product innovation and technological innovation in different stages. Xu Qingrui [9] pointed out in research that technological innovation was a process of applying new ideas to reproduction and selling related products to the market, and emphasized that product commercialization was the ultimate goal of enterprises to carry out technological innovation. The International Organization for Economic Cooperation [10] defined technological innovation as a process or product change with greater improvement, and also pointed out that product innovation was a corresponding change in the basic attributes or basic uses of the product, while process innovation was mainly important changes in the production and manufacturing process of products, such as changes in production technology and production equipment. Wilson [11] pointed out the importance of technological innovation to Japanese companies and believed that technological innovation of apparel companies was the core driving force for corporate development. Al-Jinini [12] believed that the influence of the element of knowledge capital of small- and medium-sized enterprises on the technological innovation of enterprises was the most critical, and it had played a positive role in stimulating and promoting to a greater extent. Federico [13] pointed out in the research that the technological innovation was of great help to the improvement of enterprise performance, so enterprises must pay full attention to the role of technological innovation in daily management.

In addition, some scholars have begun to study the "technological innovation effect" of OFDI. Lang [14] believed that based on the "technological innovation effect," Vietnamese enterprises would bring certain technological progress in the process of developing OFDI, and even improve the efficiency of technological innovation. Long Yong [15] believed that when high-tech enterprises develop OFDI, their technological progress would have a certain "time lag," which was called the "technical innovation effect.. Wu Jianjun [16] studied the "technological innovation effect" of OFDI in China based on the perspective of R\&D input and output, and pointed out that the appearance of this effect was closely related to the R\&D input and output of enterprises. Fan Dan [17] took Zhongguancun Science Park as an example to study the "technological innovation effect" of overseas investment by high-tech enterprises, and believed that the production of this effect was very conducive to the progress and innovation of enterprise technology.

It can be seen that some scholars have mainly focused on the relevant factors of corporate OFDI, the impact of OFDI on the economic development of the home country, the connotation and role of technological innovation, etc., but the research on the impact of China's OFDI on corporate technological innovation is relatively less. In addition, there are relatively few relevant research documents verifying the "technological innovation effect" from an empirical perspective. Therefore, Based on Chinese enterprises, this paper studies the impact of OFDI on the technological innovation by innovatively combining with "technological innovation effect." At the same time, in the process of previous studies, the data used are relatively old. At present, this paper uses the latest Chinese investment and enterprise innovation data, which can more accurately reveal the mechanism of OFDI on enterprise innovation.

By analyzing the related research conclusion of Andreani [18], Yohei [19], Rudzinski [20], and Kroodsma [21], combined with the characteristics of the research topic, this paper first chooses data matching methods, and then determines the most comparable related enterprises with OFDI enterprises as the comparison group. Secondly, the paper chooses the difference methods to verify the positive impact of corporate OFDI on corporate technological innovation, and further conducts a robustness test, that is, to calculate the "average treatment effect" with OFDI enterprises as the experimental group. Finally, this paper draws conclusions.

\section{Model Design and Data Collection}

2.1. Model Design. Using the method of double difference, this paper sets apart the enterprises that have carried out OFDI as the experimental group, and the enterprises that have not carried out OFDI as the comparison group. First, this paper determines that the dual dummy variables are $\mathrm{d} v$ and $\mathrm{d} s$, respectively. Among them, $\mathrm{d} v$ indicates as to whether the enterprise has carried out OFDI. When $\mathrm{d} v=0$, it means that the enterprise has not carried out OFDI; when $\mathrm{d} v=1$, it means that the enterprise has carried out OFDI. $\mathrm{d} s$ means 
the time dummy variable. $\mathrm{d} s=0$ means the time before OFDI of the enterprise.d $s=1$ means the time after the enterprise OFDI. Set eti $i_{i s}$ to represent the technological innovation status of enterprise $i$ in period $s$, and $\Delta$ eti $_{i}$ to represent the technological innovation changes of enterprise $i$ before or after OFDI. If an enterprise does OFDI, then the technological innovation changes in the two stages of the enterprise can be recorded as $\Delta$ eti $_{i}^{0}$; if the enterprise has never carried out OFDI, then the technological innovation changes in the two stages of the enterprise can be recorded and denoted as $\Delta$ eti $_{i}^{0}$. Therefore, after OFDI, the impact of enterprise's technological innovation $\theta$ is as follows:

$$
\theta=E\left(\theta_{i} \mid \mathrm{d} v_{i}=1\right)=E\left(\Delta \operatorname{eti}_{i}^{1} \mid \mathrm{d} v_{i}=1\right)-E\left(\Delta \operatorname{eti}_{i}^{0} \mid \mathrm{d} v_{i}=1\right) .
$$

In formula (1), judging from the development of practice, $E\left(\Delta \operatorname{eti}_{i}^{0} \mid \mathrm{d} v_{i}=1\right)$ can no longer observe accurate results, because after the OFDI, the development status of enterprises without OFDI can no longer be observed. Therefore, this paper uses the matching method to find some similar companies that have not carried out OFDI activities in China, and the changes in technological innovation of enterprises that have not yet carried out OFDI can be used to replace the changes in technological innovation of enterprises that have carried out OFDI, namely, $E\left(\Delta \mathrm{eti}_{i}^{0} \mid \mathrm{d} v_{i}=1\right)=E\left(\Delta \mathrm{eti}_{i}^{0} \mid \mathrm{d} v_{i}=0\right)$. So the new formula (1) is as follows:

$$
\theta=E\left(\theta_{i} \mid \mathrm{d} v_{i}=1\right)=E\left(\Delta \operatorname{eti}_{i}^{1} \mid \mathrm{d} v_{i}=1\right)-E\left(\Delta \operatorname{eti}_{i}^{0} \mid \mathrm{d} v_{i}=0\right) .
$$

Then, based on the method of doubling, the OFDI enterprises were used as the experimental observation group, and the enterprises that did not do OFDI were used as the comparison group. In order to compare the changes in the technological innovation level of enterprises between the experimental observation group and the enterprises in the comparison group before or after OFDI. If the enterprises in the experimental observation group have improved their technological innovation level significantly higher than those in the comparison group after OFDI, it can be proved that the implementation of OFDI has significantly stimulated the improvement of technological innovation. The verification model is as follows:

$$
\text { eti } i_{i s}=\alpha_{0}+\alpha_{1} \mathrm{~d} v+\alpha_{2} \mathrm{~d} s+\delta \mathrm{d} v \times \mathrm{d} s+\varepsilon_{i s} .
$$

In formula (3), $\mathrm{d} v$ and $\mathrm{d} s$, respectively, represent the same meaning as above; $i$ represents the enterprise; $s$ represents the time; eti $i_{i s}$ represents the technological innovation level of the enterprise, $\varepsilon_{i s}$ represents the error of the model, and $E\left(\varepsilon_{i s}\right)=0$. At the same time, in formula (3), the technological innovation levels of the enterprises in the experimental observation group before and after OFDI are $\alpha_{0}+\alpha_{1}, \alpha_{0}+\alpha_{1}+\alpha_{2}+\theta$; so, the technological innovation changes of the enterprises in the experimental observation group can be expressed as $\mathrm{E}\left(\Delta \operatorname{eti}_{i}^{1} \mid \mathrm{d} v_{i}=1\right)=\alpha_{2}+\theta$. Then, the technological innovation status of the enterprises in the comparison group before and after OFDI is $\alpha_{0}, \alpha_{0}+\alpha_{2}$, respectively. Therefore, the changes in the technological innovation level of enterprises in the comparison group can be expressed as $E\left(\Delta \operatorname{eti}_{i}^{0} \mid \mathrm{d} v_{i}=1\right)=\alpha_{2}$. Combined with formula (2), the following expression can be determined:

$$
\theta=E\left(\Delta \operatorname{eti}_{i}^{1} \mid \mathrm{d} v_{i}=1\right)-E\left(\Delta \operatorname{eti}_{i}^{0} \mid \mathrm{d} v_{i}=0\right)=\alpha_{2}+\theta-\alpha_{2}=\theta .
$$

Based on formula (4), it can be found that the coefficient $\theta$ of the interaction term $(\mathrm{d} v \times \mathrm{d} s)$ in formula (3) is the real impact on the change of the enterprise's technological innovation status after the enterprise launches OFDI activities. If $\theta>0$, it means that when the OFDI is carried out, the technological innovation level of the experimental observation group is significantly higher than that of the control group. It also means that enterprises that carry out OFDI activities can significantly improve their technological innovation level, that is, enterprises can promote the improvement of their innovation level through OFDI.

In order to strengthen the robustness of the mode, this paper further adds some control variables and effect factors in formula (3). Based on the previous scholars' research in this field, the specific control variables in this paper are as follows: enterprise capital investment (PC); number of employees participating in R\&D (TEN); enterprise establishment period (OT); whether the enterprise carries out export trade activities (WE); whether there is foreign capital injection (WO) in enterprise technical capital; whether there is $\mathrm{R} \& \mathrm{D}$ investment (WR) in the enterprise; and the economic location of the enterprise investment economic development level (OEL), degree of openness (OD), regulatory quality (RQ), and industrial agglomeration (IC). In addition, the effects in this study mainly include age effect (TE), regional effect (RE), and industrial effect (IE).

\subsection{Variables}

2.2.1. Calculation of Enterprise Technology Innovation Level (ETI). Based on the relevant research methods used by scholars such as Cantwell (1989) and Abernathy (1998) to study enterprise technological innovation, this paper determines the estimating formula of enterprise technological innovation level as follows:

$$
\mathrm{IIA}_{i s}=\beta l_{i s}+f\left(k_{i s}, m_{s}\right)+\varepsilon_{i s} .
$$

In formula (5), IIA represents the improvement of the level of technological innovation of the enterprise, $l$ represents the number of employees in the enterprise's R\&D field, $k$ represents the overall stock of corporate technology capital, $m$ represents the input, and $f\left(k_{i s}, m_{s}\right)$ represents the existence of technical capital and the function of intermediate input, and is also a third-order polynomial approximation expressed by $k$ and $m$. It can then be determined that the ETI calculation formula is as follows:

$$
\widehat{\mathrm{ETI}}_{i s}=\mathrm{IIA}_{i s}-{\widehat{\beta l_{i s}}}-{\widehat{\varphi k_{i s}}}_{\text {. }}
$$

Then, we can use the logarithmic method to calculate all the variables in formulas (5) and (6). IIA, $k$, and $m$ can be 
deflated by the product sales price index and fixed technology asset price index, respectively, and converted into actual values; the input of enterprise technology-related labor can be expressed by the average annual number of employees in the R\&D field.

2.2.2. Design of Other Variables. The capital intensity of an enterprise can be expressed by the ratio of the enterprise's fixed technology capital stock to the number of employees in the enterprise's R\&D field. Whether the enterprise is carrying out export trade activities or not is indicated by 1 and 0 ; if it is exporting, the value is 1 ; if not, the value is 0 . Whether there is foreign capital injection in the technological capital of the enterprise is represented by 1 and 0 ; if there is foreign capital injection, the value is 1 ; if there is no foreign capital injection, the value is 0 . Whether the enterprise has $\mathrm{R} \& \mathrm{D}$ investment is represented by 1 and 0 ; if there is, the value is 1 , and if not, the value is 0 .

2.3. Data Collection. In this paper, the data of the experimental observation group mainly come from the relevant data in the statistical database of China's OFDI enterprises and China's industrial enterprises calculated by the National Bureau of Statistics of China.

First, we determine the sample enterprises in the experimental control group. This paper determined the time period for the research sample to be enterprises that carried out OFDI from 2015 to 2017. During this period, the number and scale of China's OFDI enterprises were unprecedented and were at a historical high. Therefore, it will be more significant to research the effect mechanism of corporate OFDI in this period on corporate technological innovation. Combining with the data of enterprises that launched OFDI from 2015 to 2017 released by the National Bureau of Statistics, this paper eliminates the number of enterprises that have continuously invested in them and selects enterprises that have launched OFDI for the first time; this paper further excludes enterprises that have not invested more than 2 years and finally determines the sample for this research. The number of enterprises in the experimental observation group is 935 .

Secondly, the sample enterprises without OFDI activities are identified. Based on the relevant data of Chinese industrial enterprise database, this paper selects the relevant enterprise data from 2016 to 2018. The full name of the Chinese industrial enterprise database is "data of all stateowned and large-scale non-state-owned industrial enterprises (the annual main business income or sales of enterprises is more than 5 million yuan, and it is more than 20 million yuan since 2011)." The data come from the industrial survey statistics carried out by the National Bureau of Statistics of China according to the "industrial statistics reporting system." The statistical contents include the production and marketing status, financial status, cost and expense of industrial enterprises, sales of main industrial products, inventory and production capacity, as well as the prosperity of production and operation of enterprises. The relevant enterprise data used in this study are all from
Chinese industrial enterprise database published by the National Bureau of Statistics. Moreover, the relevant data of Chinese industrial enterprise database has been updated till 2018. These data provide great support and help for the latest research in this paper. In order to ensure the systematic accuracy of the research samples, this paper eliminates some enterprises with missing enterprise information indicators (such as enterprise age, total assets, enterprise identification code, etc.), some small-scale enterprises with less than $5 \mathrm{R} \& D$ personnel, and some enterprises with unclear industry. Then, combined with the Mahalanobis distance matching method, some enterprises that are similar to the experimental observation group are selected as the samples of the control group. In the end, we selected the corporate panel data from 2016 to 2018, with a sample size of 42,395.

\section{Model Checking and Results Discussion}

3.1. Comparison of Group Matching and Matching Results. In this paper, the Mahalanobis distance matching method is used to match the enterprises between the experimental observation group and the control group [22]. The matching process is as follows:

Set the experimental observation group enterprise as $p \in\left\{j_{p s}=1\right\}$, and the comparison group enterprise as $q \in\left\{j_{p s}=0\right\} ; j$ is a $0-1$ variable, representing whether the studied enterprise belongs to a certain group; $J_{p q}$ represents the Mahalanobis distance between the comparison group $q$ and the experimental observation group $p$, and the calculation formula is as follows:

$$
J_{p q}=\left(V_{p}-V_{q}\right)^{T} C^{-1}\left(V_{p}-V_{q}\right) \text {. }
$$

In formula (7), $V_{p}$ represents the vector of matching variables in the experimental observation group, $V_{q}$ represents the vector of matching variables in the comparison group, and $C$ represents the covariance matrix of the matching variables. In formula (7), when $J_{p q}$ takes the minimum value, the firm $q$ of the comparison group and the firm $p$ of the experimental observation group are the closest firms. At this time, the enterprise $q$ in this control group can be selected as the research object determined by the matching experiment. Generally speaking, if $J_{p q}$ meets the following conditions:

$$
J_{p q}=\min \left\{\left(V_{p}-V_{q}\right)^{T} C^{-1}\left(V_{p}-V_{q}\right)\right\}, \quad p \in j_{p s}, q \in j_{q s} .
$$

It means that the comparison group enterprise $q$ is the optimal value of the Mahalanobis distance matching method, and it is also the research object to be determined in this paper.

Based on the conclusions of previous relevant research literature, combined with the characteristics of the research objects in this paper, it is necessary to clarify whether the goal of the enterprise matching experiment is to find the enterprise that is most similar to the enterprise before OFDI. Therefore, this paper is based on the enterprise OFDI. The variables of the first-phase enterprise characteristics are 
matched with the sample enterprises. It is determined that the matching year of this study is between 2015 and 2017, and the enterprises that have not carried out OFDI are found to be most similar to those that have carried out OFDI in this period. The specific matching results of this study are shown in Table 1.

By observing the data in Table 1 , it can be seen that before the matching, the difference between the experimental observation group and the comparison group's enterprise sample mean value exceeds 1.9 units, which is large and particularly significant. This means that the sample enterprises in the comparison group before matching are less similar to the sample enterprises in the experimental observation group, and they are not suitable for the control group of this study. However, the mean values of the sample enterprises in the matched experimental observation group and the control group are very close, and the gap is less than 0.01 unit. This means that the control group sample enterprises are relatively similar to the experimental observation group enterprises and can be used as the sample objects for this study. And from the point of view of the $T$ value, it can accept the null hypothesis that the sample mean of the experimental observation group and the control group are equal. Therefore, it can be determined that the comparison group enterprises are 530 in 2015, 613 in 2016, and 647 in 2017. Next, this study will also determine the corresponding enterprises from 2016 to 2018 based on the experimental observation group and comparison group enterprises from 2015 to 2017.

3.2. Initial Inspection. Combined with the matching sample data in this study, the double difference method was used for the initial test. The test results are shown in Table 2. In the tests of columns (1) and (2) in Table 2, no regulatory variables are added. In the tests in columns (3)-(5), different control variables are added, respectively.

First, we examine the coefficients of $\mathrm{d} v$ and $\mathrm{d} s . \mathrm{d} v$ mainly measures the difference in technological innovation between the experimental observation group and the comparison group. That is to measure the effect of relevant factors that do not change over time on enterprise technological innovation. By observing the results of the $\mathrm{d} v$ coefficient in Table 2 , it is found that 0.362 is significantly greater than the coefficient values of $0.307,0.301,0.171$, and -0.092 in the relevant data after the control variables of the enterprise characteristics are involved. It means that, when the relevant control variables of enterprise characteristics are not involved, the technological innovation level of enterprises that carry out OFDI activities is significantly higher than that of enterprises that do not carry out OFDI. Moreover, when controlling for enterprise characteristic variables, the $\mathrm{d} v$ coefficient becomes insignificant. It means that enterprise characteristics can explain the difference in the technological innovation between the experimental observation group and the comparison group. But, after further controlling the effects of year, region, and industry, the coefficient of $\mathrm{d} v$ becomes significant at the $1 \%$ level. This means that from the perspective of year, region, and industry, the innovation level of the experimental observation group sample enterprises is significantly higher than the technological innovation level of the comparison group enterprises. It shows that the $\mathrm{d} v$ here is not robust. In addition, $\mathrm{d} s$ is a time dummy variable before and after the enterprise launches OFDI activities. By observing the $\mathrm{d} s$ coefficient data in Table 2, it can be seen that after controlling the 3 effect variables, the $\mathrm{d} s$ coefficients are all negative numbers. It shows that without considering whether enterprises have carried out OFDI activities, the technological innovation capabilities of the two sample enterprises will not improve over time.

Second, we examine the coefficient status of the interaction term $(\mathrm{d} v \times \mathrm{d} s)$. By observing the coefficients of the interaction terms in Table 2, it can be seen that regardless of whether control variables are added, the coefficients of the interaction terms are all positive, and they are all significant at the $1 \%$ level, and the results are robust. It shows that the level of technological innovation of enterprises carrying out OFDI is significantly higher than that of enterprises not carrying out OFDI. It also shows to a certain extent that the development of OFDI is conducive to enterprises to improve the level of technological innovation.

Finally, we start to consider other control variables. By observing the coefficient results in Table 2, we can see that the variables of enterprise capital, the number of technical employees, whether there are foreign equity variables, whether there are export products, whether there is $R \& D$ investment, the economic development level (OEL) of the enterprise investment area, and the degree of openness (OD), regulatory quality (RQ), and industrial agglomeration (IC) are all positive numbers. Only the coefficient sign of the company's establishment year variable is negative. It means an increase in corporate capital, an increase in the number of technical personnel, foreign shares, export products, and increased $\mathrm{R} \& \mathrm{D}$ investment. The economic development level of the company's investment area is higher, the degree of openness is higher, the quality of supervision is higher, and the industrial agglomeration is better. These conditions will promote the improvement of enterprise technological innovation level to varying degrees. This is mainly due to the inevitable need for relevant capital investment, $R \& D$ personnel investment, and R\&D capital investment in the process of enterprise technological innovation. At the same time, when foreign shares enter, it may bring certain external advanced technologies, thereby stimulating the level of technological innovation of enterprises. Moreover, enterprises that can carry out export trade must have a certain advanced technological foundation, which is conducive to enterprises to carry out higher-level technological innovation. At the same time, the high level of economic development, high degree of openness, high quality of supervision, and good industrial agglomeration in the invested areas can also stimulate the technological progress and innovation of investment enterprises to a certain extent. In addition, only the increase in the years of establishment of enterprises will inhibit the improvement of the level of technological innovation of enterprises to a certain extent. This may be due to the fact that the early establishment of the 
TABLE 1: Matching results of experimental observation group and comparison group.

\begin{tabular}{|c|c|c|c|c|c|c|c|c|c|}
\hline \multicolumn{4}{|c|}{ Before matching } & \multicolumn{3}{|c|}{ After matching } & \multirow[b]{2}{*}{$\begin{array}{c}\text { Experimental } \\
\text { observation } \\
\text { group }\end{array}$} & \multirow[b]{2}{*}{$\begin{array}{l}\text { Comparative } \\
\text { group }\end{array}$} & \multirow[b]{2}{*}{$\begin{array}{l}\text { Match } \\
\text { result }\end{array}$} \\
\hline & $\begin{array}{c}\text { ETI } \\
\text { (experimental } \\
\text { observation } \\
\text { group) }\end{array}$ & $\begin{array}{c}\text { ETI } \\
\text { (comparative } \\
\text { group) }\end{array}$ & $T$ value & $\begin{array}{c}\text { ETI } \\
\text { (experimental } \\
\text { observation } \\
\text { group) }\end{array}$ & $\begin{array}{c}\text { ETI } \\
\text { (comparative } \\
\text { group) }\end{array}$ & $\begin{array}{c}T \\
\text { value }\end{array}$ & & & \\
\hline 2015 & 7.8902 & 5.0322 & $13.12^{* * *}$ & 7.8902 & 7.9011 & 0.63 & 285 & 9022 & 530 \\
\hline 2016 & 7.9731 & 5.8391 & $30.49^{* * *}$ & 7.9731 & 7.9720 & 0.03 & 321 & 15032 & 613 \\
\hline 2017 & 7.9084 & 5.9937 & $28.43^{* * *}$ & 7.9084 & 7.9122 & 0.31 & 329 & 15442 & 647 \\
\hline
\end{tabular}

Note. ${ }^{* * *},{ }^{* *}$, and ${ }^{*}$ represent significance at the levels of $1 \%, 5 \%$, and $10 \%$, respectively.

TABLE 2: Initial inspection results.

\begin{tabular}{|c|c|c|c|c|c|}
\hline & $(1)$ & $(2)$ & (3) & (4) & (5) \\
\hline $\mathrm{d} v$ & $0.471^{* * *}(5.11)$ & $-0.193(-2.95)$ & $0.099^{* * *}(1.73)$ & $0.298^{* * *}(5.30)$ & $0.283^{* * *}(5.54)$ \\
\hline $\mathrm{d} s$ & $0.353^{* * *}(2.87)$ & $0.342^{* * *}(4.07)$ & $-0.111(-1.34)$ & $-0.072(-1.22)$ & $-0.104(-1.26)$ \\
\hline $\mathrm{d} v \times \mathrm{d} s$ & $0.492^{* * *}(3.62)$ & $0.403^{* * *}(4.21)$ & $0.311^{* * *}(4.72)$ & $0.378^{* * *}(2.55)$ & $0.462^{* * *}(4.87)$ \\
\hline $\mathrm{PC}$ & - & $0.402^{* * *}(15.03)$ & $0.433^{* * *}(13.58)$ & $0.466^{* * *}(15.22)$ & $0.471^{* * *}(15.04)$ \\
\hline TEN & - & $0.842^{* * *}(90.33)$ & $0.925^{* * *}(90.15)$ & $0.932^{* * *}(91.47)$ & $0.941^{* * *}(90.36)$ \\
\hline OT & - & $-0.015^{* * *}(-4.02)$ & $-0.007^{* * *}(-2.37)$ & $-0.012^{* * *}(-3.88)$ & $-0.009^{* * *}(-3.04)$ \\
\hline WE & - & $0.433^{* * *}(15.97)$ & $0.441^{* * *}(12.53)$ & $0.465^{* * *}(21.72)$ & $0.482^{* * *}(20.56)$ \\
\hline WO & - & $0.712^{* * *}(12.83)$ & $0.703^{* * *}(12.94)$ & $0.739^{* * *}(12.71)$ & $0.727^{* * *}(12.80)$ \\
\hline WR & - & $0.492^{* * *}(9.33)$ & $0.487^{* * *}(9.62)$ & $0.490^{* * *}(9.52)$ & $0.471^{* * *}(9.40)$ \\
\hline OEL & - & $0.552^{* * *}(14.62)$ & $0.510^{* * *}(14.84)$ & $0.537^{* * *}(14.96)$ & $0.584^{* * *}(14.25)$ \\
\hline OD & - & $0.483^{* * *}(16.42)$ & $0.493^{* * *}(16.88)$ & $0.464^{* * *}(16.91)$ & $0.422^{* * *}(16.50)$ \\
\hline RQ & - & $0.552^{* * *}(12.37)$ & $0.514^{* * *}(12.65)$ & $0.582^{* * *}(12.11)$ & $0.503^{* * *}(12.48)$ \\
\hline $\mathrm{IC}$ & - & $0.671^{* * *}(12.33)$ & $0.680^{* * *}(12.46)$ & $0.672^{* * *}(13.84)$ & $0.664^{* * *}(12.15)$ \\
\hline Constant term & $8.372^{* * *}(416.39)$ & $3.032^{* * *}(44.19)$ & $3.152^{* * *}(42.95)$ & $3.096^{* * *}(47.36)$ & $3.892^{* * *}(48.01)$ \\
\hline YE & No & No & Yes & Yes & Yes \\
\hline $\mathrm{RE}$ & No & No & No & Yes & Yes \\
\hline IE & No & No & No & No & Yes \\
\hline Observations & 8711 & 8711 & 8711 & 8711 & 8711 \\
\hline Adjusted $R^{2}$ & 0.031 & 0.682 & 0.690 & 0.833 & 0.875 \\
\hline F-value & 135.22 & 1743.09 & 1435.37 & 9054.88 & 583.05 \\
\hline
\end{tabular}

Note. ${ }^{* * *},{ }^{* *}$, and ${ }^{*}$ represent significant at the levels of $1 \%, 5 \%$, and $10 \%$, respectively, "-"means blank.

enterprise may have a backward management system and poor management flexibility, resulting in unreasonable allocation of enterprise resources, which is not conducive for the development of technological innovation activities by the enterprise.

In summary, based on the results of the initial inspection, it can be judged that after controlling the variables of the relevant characteristics of the enterprise and the related effects, the enterprises that carry out OFDI have significantly improved the level of technological innovation. It also means that there is a "technical innovation effect" in the OFDI activities of China's enterprises.

3.3. Test Based on Lag Effect. In an earlier research, it was found that China's enterprises have a "technical innovation effect" in the process of OFDI. Therefore, the process of corporate OFDI may also have a certain lag effect on technological innovation. Therefore, this paper further tests the lag effect. By observing the test results in Table 3, we can see that the coefficients of the interaction term $(\mathrm{d} v \times \mathrm{d} s)$ at a lag of 1 year and a lag of 2 years are both positive, and they are significant at different levels. It shows that there is an obvious "technological innovation effect" lag in the process of OFDI. Moreover, by observing the variation of coefficients, it can be seen that the coefficients lagging for 2 years are greater than the coefficients lagging for 1 year, and when the coefficient is lagging for 3 years, the coefficient appears to be significantly smaller. It means that in the process of developing OFDI, the investment process of the first 2 years will significantly stimulate the gradual improvement of the enterprise's technological innovation level, and in the 3rd year, the room for improvement of the enterprise's technological innovation level becomes smaller. Generally speaking, the reason for this result should be a time course for enterprises to absorb and digest new technologies in the process of developing OFDI. Only after going through this process can it promote a significant improvement in the level of enterprise technological innovation. When the technological innovation level of enterprises reaches a certain level, the stimulus effect of this round of OFDI on enterprise technological innovation will gradually decrease, that is, the marginal effect will decrease. 
TABLe 3: Test results based on lag effect.

\begin{tabular}{|c|c|c|c|c|c|c|}
\hline & \multicolumn{3}{|c|}{ No control effect } & \multicolumn{3}{|c|}{ Controlled effect } \\
\hline & (1) 1 year lag & (2) 2 years lag & (3) 3 years lag & (4) 1 year lag & (5) 2 years lag & (6) 3 years lag \\
\hline $\mathrm{d} v$ & $0.442^{* * *}(8.07)$ & $0.451^{* * *}(8.11)$ & $0.449^{* * *}(8.06)$ & $0.051^{* * *}(1.26)$ & $0.063^{* * *}(1.29)$ & $0.058^{* *}(1.23)$ \\
\hline $\mathrm{d} s$ & $0.275^{* * *}(5.93)$ & $0.314^{* * *}(6.07)$ & $0.698^{* * *}(9.11)$ & $\begin{array}{c}-0.102^{*} \\
(-1.38)\end{array}$ & $\begin{array}{l}-0.297^{*} \\
(-2.33)\end{array}$ & $0.533^{* * *}(4.51)$ \\
\hline $\mathrm{d} v \times \mathrm{d} s$ & $0.346^{* *}(3.08)$ & $0.382^{* * *}(2.44)$ & $0.207(7.14)$ & $0.331^{* * *}(3.96)$ & $0.374^{* *}(3.84)$ & $0.202(1.59)$ \\
\hline Constant term & $\begin{array}{l}9.503^{* * *} \\
(329.66)\end{array}$ & $\begin{array}{l}9.671^{* * *} \\
(341.73)\end{array}$ & $\begin{array}{l}9.103^{* * *} \\
(338.91)\end{array}$ & $\begin{array}{c}3.150^{* * *} \\
(10.22)\end{array}$ & $\begin{array}{c}3.361^{* * *} \\
(10.93)\end{array}$ & $\begin{array}{c}3.506^{* * *} \\
(11.93)\end{array}$ \\
\hline $\begin{array}{l}\text { Enterprise characteristic } \\
\text { variables }\end{array}$ & Yes & Yes & Yes & Yes & Yes & Yes \\
\hline YE & No & No & No & Yes & Yes & Yes \\
\hline $\mathrm{RE}$ & No & No & No & Yes & Yes & Yes \\
\hline IE & No & No & No & Yes & Yes & Yes \\
\hline Observations & 5803 & 4390 & 3381 & 5803 & 4390 & 3381 \\
\hline Adjusted $R^{2}$ & 0.047 & 0.041 & 0.032 & 0.886 & 0.883 & 0.875 \\
\hline F-value & 73.62 & 56.01 & 33.92 & 92.31 & 65.08 & 22.84 \\
\hline
\end{tabular}

Note. ${ }^{* * *},{ }^{* *}$, and ${ }^{*}$ represent significant at the levels of $1 \%, 5 \%$, and $10 \%$, respectively.

In addition, the coefficients of $\mathrm{d} v$ in Table 3 are always positive and significant at different levels. It shows that under the premise of not considering the time factor, the level of technological innovation of enterprises carrying out OFDI is higher. It also means that enterprises carrying out OFDI activities can stimulate the improvement of their technological innovation level.

3.4. Test Based on Investment Motivation. Based on the OFDI purpose of China's enterprises, according to the National Bureau of Statistics of China, OFDI has been classified, mainly including business service investment, production and sales investment, research and development investment, and resource mining investment. Based on previous research literature of relevant scholars, it can be found that there are certain differences in the impact of different types of OFDI on enterprise technological innovation, and the "technical innovation effects" produced.

First of all, in the process of investment, investment enterprises that develop business services can more conveniently access some of the competitors and products with higher foreign production technology, technological achievements, etc., and may also have a more direct understanding of consumers' concerns in the international market. Contents such as demand preferences and international quality standards will be more conducive to enterprises to clarify the next technological innovation goals, avoid detours, and improve the efficiency of enterprise technological innovation. Secondly, in the process of investment, enterprises that carry out production and sales investment can easily learn about the world's advanced production technology, and can also fully and efficiently use the host country's high-quality production technology and high-quality talents, so as to form certain gains. The "technological innovation effect" promotes the improvement of investment enterprises' technological innovation capabilities. Third, enterprises that carry out research and development investments can absorb foreign advanced technology through overseas mergers and acquisitions, and they can also improve their own technological innovation levels by building or participating in foreign $\mathrm{R} \& \mathrm{D}$ alliances. Finally, enterprises that carry out resource development investments are mainly meant to obtain certain resources in the host country, especially natural resources or labor resources. Most countries in the world with abundant natural resources or labor resources are developing countries and are relatively weak in terms of technology. As a result, enterprises that carry out resource development investments have a substantially reduced possibility of producing "technological innovation effects," and the possibility of stimulating enterprise technological innovation is also lower.

In short, from the perspective of past research experience and theoretical derivation, investment in business services, investment in production and marketing, and investment in research and development are more likely to promote the improvement of enterprise technological innovation; while investment in resource development is more, the possibility of increasing the level of innovation is lower. In order to test the authenticity of these theoretical derivations, this study continues to conduct corresponding tests based on investment motivation. The specific test results are shown in Table 4 .

By observing the coefficients of the interaction term $(\mathrm{d} v \times \mathrm{d} s)$ in Table 4 , it can be seen that among the four types of motivation investment, the interaction term coefficients are all positive, but only investment coefficients for business, production and sales, and R\&D are significant, while the coefficient of resource development investment is not significant. It shows that investment in business services, production and sales, and research and development will promote the improvement of the level of technological innovation of enterprises. At the same time, from the perspective of the size of the coefficient, $0.343<0.557<0.833$. It shows that from the perspective of the degree of promoting the improvement of the technological innovation level of enterprises, there is a certain difference, that is, the research and development type OFDI has the greatest effect on the promotion of the enterprise technological innovation level, followed by the production and sales type, and relatively 
TABLE 4: Test results based on investment motivation.

\begin{tabular}{|c|c|c|c|c|}
\hline & $\begin{array}{c}\text { (1) Business service } \\
\text { type }\end{array}$ & (2) Production and sales type & (3) R\&D type & $\begin{array}{c}\text { (4) Resource development } \\
\text { type }\end{array}$ \\
\hline $\mathrm{d} v$ & $0.371^{* * *}(7.02)$ & $0.228^{*}(6.73)$ & $0.672(9.11)$ & $-0.152(4.33)$ \\
\hline $\mathrm{d} s$ & $-0.105(-1.33)$ & $-0.132(-1.56)$ & $-0.172(-1.85)$ & $-0.114(-1.38)$ \\
\hline $\mathrm{d} v \times \mathrm{d} s$ & $0.343^{* * *}(4.73)$ & $0.557^{* * *}(6.11)$ & $\begin{array}{c}0.833^{* * *} \\
(9.24)\end{array}$ & $0.190(2.35)$ \\
\hline Constant term & $3.217^{* * *}(6.73)$ & $4.229^{* * *}(7.01)$ & $\begin{array}{c}4.384^{* * *} \\
(7.53)\end{array}$ & $2.791^{* * *}(4.36)$ \\
\hline $\begin{array}{l}\text { Enterprise characteristic } \\
\text { variables }\end{array}$ & Yes & Yes & Yes & Yes \\
\hline YE & Yes & Yes & Yes & Yes \\
\hline $\mathrm{RE}$ & Yes & Yes & Yes & Yes \\
\hline IE & Yes & Yes & Yes & Yes \\
\hline Observations & 4702 & 3381 & 1099 & 523 \\
\hline Adjusted $R^{2}$ & 0.843 & 0.851 & 0.887 & 0.892 \\
\hline$F$ value & 78.22 & 90.37 & 88.04 & 69.73 \\
\hline
\end{tabular}

Note. ${ }^{* * *},{ }^{* *}$, and ${ }^{*}$ represent significant at the levels of $1 \%, 5 \%$, and $10 \%$, respectively.

least effect is associated with the business service type. The reason for this situation may be: enterprises that carry out $\mathrm{R} \& \mathrm{D}$ investment are the most direct implementation of the goal of technological improvement. Its investment purpose is to improve the technological level of the enterprise itself, so it is more direct and effective to stimulate the technological innovation level of the enterprise. In terms of technological advancement in overseas production processes, enterprises with production and marketing investments are also more likely to obtain new technologies or be inspired by them, which is conducive to the improvement of their technological innovation level. Although commercial service investment can also stimulate the improvement of the technological innovation level of enterprises, since the distance between commercial service investment and the world's advanced technology is slightly farther, this type of investment has a relatively small effect on the improvement of the technological innovation level of enterprises. In addition, the coefficient of OFDI for resource development is not significant, which means that the promotion of resource development investment on the improvement of enterprise technological innovation level is not obvious. It is also mainly due to the fact that when enterprises invest in resource development, the purpose of their investment is to obtain resources, not technology. Moreover, from a global perspective, the resource-rich countries are mainly developing countries, and their industrial technology levels are low. Therefore, it is not certain that this type of investment can promote the improvement of the level of technological innovation of enterprises.

In order to be able to test whether the "technological innovation effect" of the above four motivations of OFDI has a lagging effect, this research carried out further tests.

First, the results of the lag effect test based on commercial service and production-sale investment are shown in Table 5. By observing the coefficients of the interaction term $(\mathrm{d} v \times \mathrm{d} s)$, it can be seen that the coefficients in columns (1) -(3) are all positive. Moreover, the coefficient is increasing when the lag is 1 year and 2 years. When the lag is 3 years, the coefficient drops drastically and is not significant. Its coefficient drops drastically, and the coefficient is not significant after a lag of 3 years. It means that the stimulus effect of commercial service investment on enterprise technological innovation in the first two years is increasing, and by the third year, this stimulus effect has become insignificant. The coefficients of the interaction terms in columns (4)-(6) are all positive and significant, and the coefficients change firstly and then decrease. It also shows that the stimulus effect of production and marketing investment on enterprise technological innovation shows a situation of first being strong and then weak. The main reason for this situation is that although these two forms of investment can understand the new level of technological development in the world, the production and marketing investment is more efficient in the absorption and application of new technologies. They stimulate the enterprise technological innovation. It is more intense and significant.

Secondly, the test results based on the lag effect of R\&D and resource development investments are shown in Table 6. By observing the coefficients of the interaction term $(\mathrm{d} v \times \mathrm{d} s)$ in Table 6 , it can be found that the coefficients of the research and development OFDI in columns (1)-(3) are all positive and significant, and show a continuous increasing trend. It shows that the promotion of R\&D OFDI to enterprise technological innovation is continuous. This is mainly because the core goal of $\mathrm{R} \& \mathrm{D}$ investment is to improve the technological level of enterprises, so that the R\&D investment will continue to stimulate the improvement of the level of technological innovation of enterprises over time. Judging from the interaction term coefficients in columns (4)-(6), none of them are significant. It shows that the impact of resource development investment on enterprise technological innovation is not obvious.

3.5. Test Based on the Income Level of the Investment Host Country. Rudzinski [20], Kroodsma [21], and Fan [17] all believe that the "technological innovation effect" produced by OFDI activities of enterprises that invest in countries with different income levels has a certain impact on the 
TABle 5: Test results based on the lag effect of the commercial service and production and sales OFDI.

\begin{tabular}{|c|c|c|c|c|c|c|}
\hline & \multicolumn{3}{|c|}{ Commercial service OFDI } & \multicolumn{3}{|c|}{ Production and sales OFDI } \\
\hline & (1) 1 year lag & (2) 2 years lag & (3) 3 years lag & (4) 1 year lag & (5) 2 years lag & (6) 3 years lag \\
\hline $\mathrm{d} v$ & $0.253^{*}(4.31)$ & $0.302^{* * *}(4.74)$ & $0.202^{* *}(4.17)$ & $-0.175(-2.03)$ & $-0.132(-1.88)$ & $0.154(2.90)$ \\
\hline $\mathrm{d} s$ & $-0.053(-1.22)$ & $-0.062(-1.47)$ & $-0.087(-1.95)$ & $-0.257(-1.93)$ & $-0.288(-2.37)$ & $-0.291(-2.88)$ \\
\hline $\mathrm{d} v \times \mathrm{d} s$ & $0.054^{*}(0.73)$ & $0.066^{* *}(0.89)$ & $0.017(0.25)$ & $0.409^{* * *}(11.67)$ & $0.438^{* * *}(12.99)$ & $0.423^{* *}(12.30)$ \\
\hline Constant term & $3.006^{* * *}(6.93)$ & $3.174^{* * *}(6.80)$ & $3.282^{* * *}(7.15)$ & $3.659^{* * *}(7.22)$ & $3.472^{* * *}(7.30)$ & $3.110^{* * *}(6.54)$ \\
\hline Enterprise characteristic variables & Yes & Yes & Yes & Yes & Yes & Yes \\
\hline YE & Yes & Yes & Yes & Yes & Yes & Yes \\
\hline $\mathrm{RE}$ & Yes & Yes & Yes & Yes & Yes & Yes \\
\hline IE & Yes & Yes & Yes & Yes & Yes & Yes \\
\hline Observations & 2703 & 1891 & 2084 & 2502 & 3138 & 1905 \\
\hline Adjusted $R^{2}$ & 0.664 & 0.683 & 0.657 & 0.612 & 0.690 & 0.637 \\
\hline$F$ value & 90.47 & 92.36 & 71.99 & 66.02 & 67.31 & 54.33 \\
\hline
\end{tabular}

Note. ${ }^{* * *},{ }^{* *}$, and ${ }^{*}$ represent significant at the levels of $1 \%, 5 \%$, and $10 \%$, respectively.

TABLE 6: Test results based on the lag effect of R\&D and resource development OFDI.

\begin{tabular}{|c|c|c|c|c|c|c|}
\hline & \multicolumn{3}{|c|}{ R\&D OFDI } & \multicolumn{3}{|c|}{ Resource development OFDI } \\
\hline & (1) 1 year lag & (2) 2 years lag & (3) 3 years lag & (4) 1 year lag & (5) 2 years lag & (6) 3 years lag \\
\hline $\mathrm{d} v$ & $2.553^{* * *}(4.02)$ & $2.692^{* * *}(4.33)$ & $2.046^{* * *}(3.62)$ & $1.384(2.11)$ & $1.547(2.36)$ & $2.604(4.51)$ \\
\hline $\mathrm{d} s$ & $1.294^{* * *}(2.13)$ & $1.316^{* * *}(2.64)$ & $1.004^{* * *}(1.83)$ & $0.241(1.46)$ & $0.254(1.59)$ & $0.117(1.20)$ \\
\hline $\mathrm{d} v \times \mathrm{d} s$ & $\begin{array}{c}0.673^{* * *} \\
(22.37)\end{array}$ & $\begin{array}{c}0.697^{* * *} \\
(25.04)\end{array}$ & $\begin{array}{c}0.699^{* * *} \\
(20.15)\end{array}$ & $0.031(0.17)$ & $0.025(0.14)$ & $-0.045(-0.25)$ \\
\hline Constant term & $\begin{array}{c}7.553^{* * *} \\
(82.21)\end{array}$ & $\begin{array}{c}7.803^{* * *} \\
(78.37)\end{array}$ & $\begin{array}{c}7.392^{* * *} \\
(79.50)\end{array}$ & $\begin{array}{c}5.943^{* * *} \\
(53.97)\end{array}$ & $\begin{array}{c}4.176^{* * *} \\
(43.69)\end{array}$ & $\begin{array}{c}4.536^{* * *} \\
(38.28)\end{array}$ \\
\hline $\begin{array}{l}\text { Enterprise characteristic } \\
\text { variables }\end{array}$ & Yes & Yes & Yes & Yes & Yes & Yes \\
\hline YE & Yes & Yes & Yes & Yes & Yes & Yes \\
\hline $\mathrm{RE}$ & Yes & Yes & Yes & Yes & Yes & Yes \\
\hline IE & Yes & Yes & Yes & Yes & Yes & Yes \\
\hline Observations & 905 & 783 & 512 & 203 & 117 & 125 \\
\hline Adjusted $R^{2}$ & 0.593 & 0.652 & 0.615 & 0.580 & 0.532 & 0.569 \\
\hline$F$ value & 92.33 & 85.26 & 70.63 & 72.11 & 70.35 & 64.28 \\
\hline
\end{tabular}

Note. ${ }^{* * *},{ }^{* *}$, and ${ }^{*}$ represent significant at the levels of $1 \%, 5 \%$, and $10 \%$, respectively.

improvement of technological level. According to data released by the World Bank in 2017, countries with a per capita national income of more than US\$12,235 are high-income countries, and countries with lower income levels are lowincome countries. Therefore, in order to verify the "technological innovation effect" of OFDI in host countries with different income levels, this research has carried out further verification [23].

Firstly, the test results based on the income level of the investment host country are shown in Table 7 . By observing the coefficient of the interaction term $(\mathrm{d} v \times \mathrm{d} s)$, it can be found that the coefficients of the interaction term in columns (1) and (2) in Table 7 are both significant and positive. It shows whether it is investing in high-income countries or investing in low-income countries that can stimulate the improvement of the level of technological innovation of enterprises. At the same time, it can also be seen that the coefficient 0.493 is significantly greater than 0.206 . It shows that investment in high-income countries is significantly better than investment in low-income countries in terms of promoting the improvement of enterprise technological innovation. The main reason for this situation is that generally high-income countries have relatively strong technological foundations, so when enterprises invest in high-income countries, they can more directly and efficiently absorb high-quality technologies from high-income countries. Therefore, the "technological innovation effect" of OFDI carried out in high-income countries has a greater impact, and this kind of OFDI can more efficiently promote the improvement of the level of technological innovation of enterprises. It can be seen that investing in both high-income countries and low-income countries can promote the improvement of enterprise innovation, but the promotion effect of high-income countries is more significant.

'Secondly, the test results based on the lag effect of the investment host country are shown in Table 8. By observing the coefficient of the interaction term $(\mathrm{d} v \times \mathrm{d} s)$ in Table 8 , it can be found that the interaction term coefficients of investing in high-income countries are all significant, positive, and first increase and then decrease. It means that investing in high-income countries can significantly promote the improvement of enterprise technological innovation. Because investment in highincome countries can better absorb the advanced industrial technology of high-income countries, however, after a period of time, when the technological level of the 
TABLE 7: Test results based on the income level of the investment host country.

\begin{tabular}{|c|c|c|}
\hline & (1) High-income countries & (2) Low-income countries \\
\hline $\mathrm{d} v$ & $0.227^{* * *}(5.03)$ & $0.205^{* * *}(5.01)$ \\
\hline $\mathrm{d} s$ & $-0.135^{* *}(2.75)$ & $-0.094^{*}(2.16)$ \\
\hline $\mathrm{d} v \times \mathrm{d} s$ & $0.493^{* * *}(8.07)$ & $0.206^{* * *}(3.48)$ \\
\hline Constant term & $6.043^{* * *}(17.38)$ & $6.552^{* * *}(20.19)$ \\
\hline Enterprise characteristic variables & Yes & Yes \\
\hline YE & Yes & Yes \\
\hline $\mathrm{RE}$ & Yes & Yes \\
\hline IE & Yes & Yes \\
\hline Observations & 4032 & 3871 \\
\hline Adjusted $R^{2}$ & 0.699 & 0.703 \\
\hline$F$ value & 90.54 & 72.16 \\
\hline
\end{tabular}

Note. ${ }^{* * *},{ }^{* *}$, and ${ }^{*}$ represent significant at the levels of $1 \%, 5 \%$, and $10 \%$, respectively.

TABLE 8: Test results based on the lag effect of the investment host country.

\begin{tabular}{|c|c|c|c|c|c|c|}
\hline & \multicolumn{3}{|c|}{ Invest in high-income countries } & \multicolumn{3}{|c|}{ Invest in low-income countries } \\
\hline & (1) 1 year lag & (2) 2 years lag & (3) 3 years lag & (4) 1 year lag & (5) 2 years lag & (6) 3 years lag \\
\hline $\mathrm{d} v$ & $0.216^{* * *}(4.63)$ & $0.247^{* * * *}(5.70)$ & $0.284^{* *}(5.96)$ & $0.204^{* * *}(4.14)$ & $0.296^{*}(5.88)$ & $0.215(5.23)$ \\
\hline $\mathrm{d} s$ & $-0.142^{* * *}(2.63)$ & $-0.115^{* * *}(2.34)$ & $-0.162^{* *}(2.74)$ & $-0.098^{* * *}(2.05)$ & $-0.091^{* *}(1.95)$ & $-0.093(1.99)$ \\
\hline $\mathrm{d} v \times \mathrm{d} s$ & $0.351^{* * *}(6.07)$ & $0.509^{* * *}(9.68)$ & $0.477^{* *}(8.31)$ & $0.237^{* * *}(1.34)$ & $0.280^{*}(1.94)$ & $0.572(10.66)$ \\
\hline Constant term & $6.172^{* *}(17.61)$ & $6.064^{* * *}(18.56)$ & $6.162^{* *}(20.55)$ & $6.037^{* * *}(15.91)$ & $6.447^{* *}(23.85)$ & $6.503(22.79)$ \\
\hline $\begin{array}{l}\text { Enterprise characteristic } \\
\text { variables }\end{array}$ & Yes & Yes & Yes & Yes & Yes & Yes \\
\hline YE & Yes & Yes & Yes & Yes & Yes & Yes \\
\hline $\mathrm{RE}$ & Yes & Yes & Yes & Yes & Yes & Yes \\
\hline IE & Yes & Yes & Yes & Yes & Yes & Yes \\
\hline Observations & 3965 & 3657 & 3091 & 3415 & 3292 & 2976 \\
\hline Adjusted $R^{2}$ & 0.673 & 0.652 & 0.661 & 0.687 & 0.690 & 0.679 \\
\hline$F$-value & 89.33 & 86.52 & 80.61 & 71.32 & 70.56 & 69.83 \\
\hline
\end{tabular}

Note. ${ }^{* * *},{ }^{* *}$, and ${ }^{*}$ represent significant at the levels of $1 \%, 5 \%$, and $10 \%$, respectively.

investment enterprise reaches a higher level, the speed of the improvement of the enterprise's technological innovation level will also slow down. In addition, from the perspective of the interaction coefficient of investment in low-income countries, the first 2 years are significantly positive, and the $3 \mathrm{rd}$ year is not significant. This shows that although the "technological innovation effect" of investment in low-income countries has a lagging effect, the stimulus effect on technological innovation is relatively weak and its sustainability is insufficient. It can be seen that there is a certain lag in the "technological innovation effect" of investment in host countries with different income levels, and compared with investing in low-income countries, enterprises investing in high-income countries are more sustainable in stimulating technological innovation.

\section{ATT Test Based on Bias Score}

In order to further verify the robustness of the previous research results, this paper further tests the results. By combing the relevant research literature of Jiang [22] and other scholars, this study finally chooses the average effect of the treatment on the treated (ATT) test method based on the bias score, and determines the specific calculation formula of the ATT test method as follows:

$$
\mathrm{ATT}=\frac{1}{M} \sum_{i}\left(\mathrm{eti}_{i z}^{1}-\sum_{a \in C(i)} \gamma_{i a} \mathrm{eti}_{a z}^{0}\right)
$$

In formula (9), eti ${ }_{i z}^{1}$ and eti $\mathrm{t}_{a z}^{0}$ represent the technological innovation level of the experimental observation group and the comparison group, respectively, $C(i)$ represents the set of enterprises matched with the experimental observation group, and $\gamma_{i a}$ represents the enterprise $i$, the weight of matched firm $a$, and $M$ represents the total number of firm pairs.

Then, different estimates are made according to the time when the enterprise started OFDI, and the results are shown in Tables 9-11. By observing the data in Table 9, it can be seen that the estimated value in 2015 is 0.2639 , which is a positive and significant number, which means that on the whole, enterprises' OFDI can significantly promote the improvement of their technological innovation level. In terms of investment motivation, business service investment, production and marketing investment, and R\&D investment can all promote the improvement of enterprise technological innovation to varying degrees. The resource development investment has partially promoted the improvement of the level of technological innovation of enterprises. At the same time, investment in high-income countries has a more significant effect on the promotion of 
TABLe 9: ATT inspection (2015).

\begin{tabular}{|c|c|c|c|c|c|c|c|c|c|c|}
\hline & (1) Mixing & $\begin{array}{c}(2) \\
\text { Business } \\
\text { service }\end{array}$ & $\begin{array}{c}\text { (3) } \\
\text { Production } \\
\text { and sales }\end{array}$ & (4) $\mathrm{R} \& \mathrm{D}$ & $\begin{array}{l}\text { (5) Resource } \\
\text { development }\end{array}$ & $\begin{array}{l}\text { (6) High- } \\
\text { income } \\
\text { countries }\end{array}$ & $\begin{array}{c}\text { (7) Low- } \\
\text { income } \\
\text { countries }\end{array}$ & $\begin{array}{l}\text { (8) } 1 \text { year } \\
\text { lag }\end{array}$ & $\begin{array}{l}\text { (9) } 2 \text { years } \\
\text { lag }\end{array}$ & $\begin{array}{c}(10) 3 \\
\text { years lag }\end{array}$ \\
\hline ETI & $\begin{array}{c}0.2639^{* * *} \\
(7.043)\end{array}$ & $\begin{array}{c}0.1502^{* * *} \\
(3.117)\end{array}$ & $\begin{array}{c}0.3425^{* * *} \\
(8.405)\end{array}$ & $\begin{array}{c}0.3871^{* * *} \\
(9.616)\end{array}$ & $\begin{array}{l}0.1832 \\
(3.872)\end{array}$ & $\begin{array}{c}0.3771^{* * *} \\
(8.872)\end{array}$ & $\begin{array}{c}0.1546^{* *} \\
(3.472)\end{array}$ & $\begin{array}{c}0.0182^{* * *} \\
(1.539)\end{array}$ & $\begin{array}{c}0.2205^{* * *} \\
(5.382)\end{array}$ & $\begin{array}{c}0.2082^{* * *} \\
(4.106)\end{array}$ \\
\hline $\begin{array}{l}\text { Experimental } \\
\text { group }\end{array}$ & 304 & 48 & 107 & 114 & 35 & 174 & 130 & 127 & 105 & 72 \\
\hline $\begin{array}{l}\text { Comparison } \\
\text { group }\end{array}$ & 42095 & 33501 & 32415 & 40825 & 30329 & 37914 & 37905 & 14022 & 13098 & 14975 \\
\hline
\end{tabular}

Note: ${ }^{* * *},{ }^{* *}$, and ${ }^{*}$ represent significant at the levels of $1 \%, 5 \%$, and $10 \%$, respectively.

TABLE 10: ATT inspection (2016).

\begin{tabular}{|c|c|c|c|c|c|c|c|c|c|}
\hline & (1) Mixing & $\begin{array}{c}\text { (2) } \\
\text { Business } \\
\text { service }\end{array}$ & $\begin{array}{c}\text { (3) } \\
\text { Production } \\
\text { and sales }\end{array}$ & (4) $\mathrm{R} \& \mathrm{D}$ & $\begin{array}{l}\text { (5) Resource } \\
\text { development }\end{array}$ & $\begin{array}{l}\text { (6) High- } \\
\text { income } \\
\text { countries }\end{array}$ & $\begin{array}{l}\text { (7) Low- } \\
\text { income } \\
\text { countries }\end{array}$ & $\begin{array}{l}\text { (8) } 1 \text { year } \\
\text { lag }\end{array}$ & $\begin{array}{l}\text { (9) } 2 \text { years } \\
\text { lag }\end{array}$ \\
\hline ETI & $\begin{array}{c}0.2447^{* * *} \\
(5.011)\end{array}$ & $\begin{array}{c}0.2691^{* * *} \\
(6.628)\end{array}$ & $\begin{array}{c}0.2733^{* * *} \\
(7.037)\end{array}$ & $\begin{array}{c}0.2903^{* * *} \\
(7.483)\end{array}$ & $0.1149(4.330)$ & $\begin{array}{c}0.4100^{* * *} \\
(8.253)\end{array}$ & $\begin{array}{c}0.2064^{* *} \\
(6.339)\end{array}$ & $\begin{array}{c}0.2056^{* * *} \\
(6.009)\end{array}$ & $\begin{array}{c}0.2497^{* * *} \\
(6.461)\end{array}$ \\
\hline $\begin{array}{l}\text { Experimental } \\
\text { group }\end{array}$ & 426 & 99 & 105 & 141 & 81 & 217 & 209 & 254 & 172 \\
\hline $\begin{array}{l}\text { Comparison } \\
\text { group }\end{array}$ & 29067 & 25439 & 26703 & 28941 & 25043 & 27783 & 28099 & 15438 & 13692 \\
\hline
\end{tabular}

Note: ${ }^{* * *},{ }^{* *}$, and ${ }^{*}$ represent significant at the levels of $1 \%, 5 \%$, and $10 \%$, respectively.

TABLE 11: ATT inspection (2017).

\begin{tabular}{|c|c|c|c|c|c|c|c|}
\hline & (1) Mixing & $\begin{array}{l}\text { (2) Business } \\
\text { service }\end{array}$ & $\begin{array}{l}\text { (3) Production } \\
\text { and sales }\end{array}$ & (4) R\&D & $\begin{array}{l}\text { (5) Resource } \\
\text { development }\end{array}$ & $\begin{array}{l}\text { (6) High- } \\
\text { income } \\
\text { countries }\end{array}$ & $\begin{array}{l}\text { (7) Low-income } \\
\text { countries }\end{array}$ \\
\hline ETI & $\begin{array}{c}0.2105^{* * *} \\
(5.331)\end{array}$ & $\begin{array}{c}0.2305^{* * *} \\
(6.204)\end{array}$ & $\begin{array}{c}0.2788^{* * *} \\
(7.993)\end{array}$ & $\begin{array}{c}0.3154^{* * * *} \\
(8.440)\end{array}$ & $0.0921(2.117)$ & $\begin{array}{c}0.4502^{* * *} \\
(9.226)\end{array}$ & $0.2094^{* *}(5.003)$ \\
\hline $\begin{array}{l}\text { Experimental } \\
\text { group }\end{array}$ & 633 & 141 & 159 & 231 & 102 & 325 & 308 \\
\hline $\begin{array}{l}\text { Comparison } \\
\text { group }\end{array}$ & 14983 & 12032 & 13962 & 13673 & 11342 & 13058 & 12003 \\
\hline
\end{tabular}

Note. ${ }^{* * *},{ }^{* *}$, and ${ }^{*}$ represent significant at the levels of $1 \%, 5 \%$, and $10 \%$, respectively.

enterprise technological innovation than investment in lowincome countries [24]. In terms of the lag effect of technological innovation, there has been an increase and then a decrease. All in all, through research and testing, it can be determined that OFDI can promote the improvement of enterprise technological innovation level. Furthermore, the estimated data results in Tables 10 and 11 indicate that the results are basically consistent with the data conclusions in Table 9. Moreover, these test results are consistent with the previous argumentation conclusions. This also means that the previous research conclusions have strong robustness [25].

In order to be able to ensure the robustness of the research conclusions more comprehensively, this paper refers to the relevant research conclusions of scholars such as Boroomand [26] and Tilton [27], and further conducts robustness tests based on relevant measurement indicators of enterprise innovation capabilities. Hsieh [28] believes that R\&D investment indicators can measure the size of enterprise innovation capabilities to a certain extent. Lana [29] argues that the number of patents a company applies for each year can also reflect the innovation level of the company to a certain extent. Tan [30] considers that the high-skilled labor ratio indicator can also show the development status of enterprise innovation capabilities to a certain extent. Davey's [31] innovation value realization index will also reflect a certain enterprise's innovation capability.

Based on the research of the above scholars, this paper further uses different indicators to measure the innovation ability of enterprises and launches the corresponding robustness test. The test results are shown in Table 12. By observing the data results in the chronological order in column (1) of the ATT test in Table 12, we can find that the changes in the numerical values of these indicators that reflect the company's innovation capabilities are consistent with the previous research conclusions. It also means that the previous research conclusions have strong robustness. 
TABLE 12: ATT test based on relevant measurement indicators of enterprise innovation capability.

\begin{tabular}{|c|c|c|c|c|c|c|}
\hline & & (1) Mixing & $\begin{array}{l}\text { (2) } \mathrm{R} \& \mathrm{D} \\
\text { investment }\end{array}$ & $\begin{array}{c}\text { (3) Number of patent } \\
\text { applications }\end{array}$ & $\begin{array}{l}\text { (4) Proportion of highly } \\
\text { skilled workers }\end{array}$ & $\begin{array}{l}\text { (5) Innovation value } \\
\text { realization }\end{array}$ \\
\hline \multirow{3}{*}{ ETI } & 2015 & $0.3492^{* * *}(6.219)$ & $0.3021^{* * *}(5.994)$ & $0.3149^{* * *}(5.871)$ & $0.1542^{* * *}(3.058)$ & $0.5737^{* * *}(6.481)$ \\
\hline & 2016 & $0.3207^{* * *}(6.162)$ & $0.3842^{* *}(6.429)$ & $0.2984^{* * *}(5.804)$ & $0.3599^{* *}(6.273)$ & $0.3374^{* *}(6.592)$ \\
\hline & 2017 & $0.3027^{* * *}(6.947)$ & $0.4172 * *(7.442)$ & $0.2838^{* *}(6.547)$ & $0.2994^{* * *}(6.430)$ & $0.3126^{* * *}(6.746)$ \\
\hline
\end{tabular}

Note. ${ }^{* * *},{ }^{* *}$, and ${ }^{*}$ represent significant at the levels of $1 \%, 5 \%$, and $10 \%$, respectively.

\section{Conclusions}

Based on relevant data from 2015 to 2017, this paper examines the impact of OFDI on China's enterprise technological innovation and conducts relevant research, especially in conjunction with the "technical innovation effect" in the enterprise investment process. The research of this paper has reached the following 3 main conclusions: (1) The increase in enterprise capital, the increase in the number of technical personnel, the participation of foreign shares, the increase in export products, and the increase in R\&D investment will all promote the improvement of the level of enterprise technological innovation, and the influence will have a certain lag effect and present a trend of increasing first and then decreasing. However, with the increase of the establishment years of enterprises, it will restrain the improvement of the technological innovation level of enterprises to a certain extent. (2) OFDI of business service type, production and sales type, and R\&D type will promote the improvement of enterprise technological innovation level to varying degrees. In particular, the research and development OFDI will promote the improvement of the technological innovation level of enterprises to a greater extent. The resource development-oriented OFDI does not necessarily promote the improvement of enterprise technological innovation level. (3) When carrying out OFDI for host countries with different income levels, and investing in host countries with low-income levels, investment in host countries with highincome levels has a greater role in promoting technological innovation of enterprises. Moreover, the above conclusions have passed the ATT test, and the conclusions are robust.

Based on the above research conclusions, China's enterprises participating in OFDI can take measures such as strengthening corporate capital investment, increasing technical personnel, attracting foreign investment, actively exporting products, and increasing $R \& D$ investment to promote the improvement of corporate technology. Moreover, enterprises can increase their investment in highincome countries by increasing OFDI in business service, production and sales, and R\&d directions, and further promote the improvement of their technological innovation level. At the same time, relevant government management departments can increase their guidance to enterprises and provide important policy and institutional guarantees for improving their technological innovation level.

\section{Data Availability}

The data used to support the findings of this study are available from the corresponding author upon request.

\section{Conflicts of Interest}

The authors declare no conflicts of interest.

\section{Acknowledgments}

The authors thank funding supports from Basic Research Business Expenses Research Project of Provincial Colleges and Universities in Heilongjiang Province (Grant No. HDYJW201907), Humanities and Social Science Project of the Ministry of Education of China (Grant No. 20YJC790082), Chinese Postdoctoral Science Foundation (Grant No. 2020M681537), Philosophy and Social Science Research Planning Project of Heilongjiang Province (Grant No. 19JLC117), and National Social Science Fund of China (Grant No. 17BGL204).

\section{References}

[1] P. J. Buckley, L. J. Clegg, A. R. Cross, H. Voss, and P. Zheng, "Erratum: the determinants of Chinese outward foreign direct investment," Journal of International Business Studies, vol. 40, no. 2, pp. 353-354, 2009.

[2] I. Liu and D. Sutherland, "Do China's "national team" business groups undertake strategic-asset-seeking OFDI?" Chinese Management Studies, vol. 3, no. 1, pp. 11-24, 2009.

[3] A. Verbeke, "The JIBS 2017 Decade Award: the determinants of Chinese outward foreign direct investment," Journal of International Business Studies, vol. 49, no. 1, pp. 1-3, 2018.

[4] F. Nie and H. Liu, "The impact of China's OFDI on the scale and quality of IFDI: theoretical mechanism and empirical evidence," International Trade Issues, vol. 433, no. 1, pp. 97-109, 2019.

[5] Q. Zhang, F. Li, and B. Cheng, "Bilateral political relations, host country institutional environment and China's OFDI location choice: based on the research of countries along the One Belt One Road," International Economics and Trade Research, vol. 35, no. 6, pp. 89-103, 2019.

[6] S. Borghesi, C. Franco, and G. Marin, "Outward foreign direct investment patterns of Italian firms in the European Union's emission trading scheme," The Scandinavian Journal of Economics, vol. 122, no. 2, pp. 219-256, 2020.

[7] J. Cantwell, "Technological innovation and multinational corporations," The Economic Journal, vol. 100, no. 401, pp. $102-117,1989$.

[8] T. Abernathy, "A brief tutorial on the development of measures for use in survey questionnaires," Organizational Esearch Methos, vol. 54, no. 1, pp. 104-121, 1998.

[9] Q. Xu and B. Guo, "Technological innovation of Chinese enterprises--Combined innovation based on core competence," Journal of Management Engineering, vol. 14, no. 12, pp. 1-9, 2000. 
[10] OECD, The Measurement of Scientific and Technological Activities Oslo Manual, Guidelines for Collecting And Interpreting Innovation Data, pp. 47-52, OECD Eurostat, Paris, France, 2005.

[11] A. Wilson, "Technical innovation," Twist, vol. 45, no. 99, pp. 44-47, 2019.

[12] D. Al-Jinini, S. Dahiyat, and N. Bontis, "Intellectual capital, entrepreneurial orientation, and technical innovation in small and medium-sized enterprises," Knowledge \& Process Management, vol. 31, no. 6, pp. 132-157, 2019.

[13] M. Federico and B. Daniele, "Inbound open innovation and firm performance," Journal of Innovation \& Knowledge, vol. 5, no. 1, pp. 1-19, 2020.

[14] T. M. Lang, S. H. Lin, and T. N. T. Vy, "Mediate effect of technology innovation capabilities investment capability and firm performance in Vietnam," Procedia - Social and Behavioral Sciences, vol. 40, no. 1, pp. 817-829, 2012.

[15] Y. Long and P. Shi, "The impact of venture capital on the technological innovation effect of high-tech enterprises," Economics and Management Research, vol. 63, no. 7, pp. 38-44, 2012.

[16] J. Wu and Y. Qiu, "The technological innovation effect of China's foreign direct investment: an analytical perspective based on R\&D input and output," Contemporary Economic Science, vol. 95, no. 1, pp. 75-80, 2013.

[17] D. Fan, E. Zhang, and S. Xiao, "Research on the technological innovation effect of overseas investment by high-tech enterprises--Take Zhongguancun Science Park as an example," Industrial Innovation Research, vol. 34, no. 7, pp. 19-22, 2018.

[18] C. Andreani, D. Colognesi, E. Degiorgi et al., "difference method in deep inelastic neutron scattering on the VESUVIO spectrometer," Nuclear Instruments and Methods in Physics Research Section A: Accelerators, Spectrometers, Detectors and Associated Equipment, vol. 497, no. 2-3, pp. 535-549, 2003.

[19] Y. Filabozzi, T. Tetsuya, and O. Kazushige, "Well-resolved hypocenter distribution using the double-difference relocation method in the region of the 2007 Chuetsu-oki Earthquake," Earth Planets \& Space, vol. 60, no. 11, pp. 1105-1109, 2008.

[20] L. Rudzinski and W. Dębski, "Relocation of mining-induced seismic events in the Upper Silesian Coal Basin, Poland, by a double-difference method," Acta Geodynamica Et Geomaterialia, vol. 5, no. 2, pp. 97-104, 2008.

[21] R. A. Kroodsma and C. S. Ruf, “-calibration of Microwave radiometers using the vicarious cold calibration double difference method," IEEE Journal of Selected Topics in Applied Earth Observations and Remote Sensing, vol. 5, no. 3, pp. 1006-1013, 2012.

[22] G. Jiang and D. Jiang, "China's industrial enterprises' outward direct investment and enterprise productivity progress," World Economy, vol. 8, no. 9, pp. 53-76, 2014.

[23] H. McKague, D. Peng, and L. Wang, "Research on utility evaluation of grid investment considering risk preference of decision-makers," Mathematical Problems in Engineering, vol. 2020, no. 8, 16 pages, Article ID 3568470, 2020.

[24] G. Zhang, S. Cheng, Z. LI, and M. Cao, "A reinsurance and investment game between two insurers under the CEV model," Mathematical Problems in Engineering, vol. 2020, no. 7, 12 pages, Article ID 4696941, 2020.

[25] Y. Yuan, F. Cai, and LL. Yang, "Renewable energy investment under carbon emission regulations," Sustainability, vol. 12, no. 17, pp. 1-15, 2020.

[26] C. Tilton, J. Markowitz, and Y. Seto, "Robustness test," Encyclopedia of Biometrics, vol. 2, no. 5, pp. 98-114, 2009.
[27] B. Boroomand and O. C. Zienkiewicz, "An improved REP recovery and the effectivity robustness test," International Journal for Numerical Methods in Engineering, vol. 40, no. 17, pp. 3247-3277, 1997.

[28] H. Hsieh, Y. Wu, W. Lu et al., "Assessing and ranking the innovation ability and business performance of global companies in the aerospace and defense industry," Managerial and Decision Economics, vol. 41, no. 1, pp. 40-56, 2020.

[29] Y. Lana, "The implementation of activity-based costing in China: an innovation action research approach," The British Accounting Review, vol. 39, no. 3, pp. 249-264, 2007.

[30] J. Tan, E. Fischer, and R. Mitchell, "At the center of the action: innovation and technology strategy research in the small business setting," Journal of Small Business Management, vol. 47, no. 3, pp. 233-262, 2009.

[31] C. L. Phan, J. Powell, J. E. Powell et al., "Innovation, construction SMEs and action learning," Engineering, Construction and Architectural Management, vol. 11, no. 4, pp. 230-237, 2004. 